\title{
Oswaldofllaria chabaudi N. SP. (Nematoda: Onchocercidae) FROM A SOUTH AMERICAN TROPIDURID LIZARD (SQUAMATA: IGUANIA) WITH AN UPDATE ON OSWALDOFILARIINAE
}

\author{
PEREIRA F.B.* ${ }^{*}$ SOUZA LIMA S.**** B BIN O.****
}

\section{Summary:}

A new species of Oswaldofilaria is described from Tropidurus torquatus (Tropiduridae: Iguania); its prevalence at the rocky study area at Juiz de Fora, Minas Gerais, Brazil, was approximately $30 \%$ and its mean intensity $3.13 \pm 2.51$. Oswaldofilaria chabaudi n. sp. is distinct from the thirteen Oswaldofilaria species known in Australia, Africa and South-America in having the following characteristics: oesophagus medium-sized, left spicule $1 \mathrm{~mm}$ long and high spicular ratio (about 5), tail extremity ornated in both sexes with a bifurcated projection, and tooth-like structures near phasmids in the female. A long left spicule and high spicular ratio are convergent derived characters also found in a parasite of Australian crocodilians, $O$. kanbaya, and in several species of the puertoricensis from polychrotids. Oswaldofilaria in South America is represented by eight species. Within these, a primitive group that is parasitic in Iguanidae, Polychrotidae (Iguania) and Crocodylidae and that possesses a long oesophagus is recognised, together with two distinct derived lines: three species with numerous, aligned precloacal papillae, parasitic in Teiidae (Laterata) and Scincidae (Scincomorpha), and $O$. chabaudi n. sp., in which this character is absent. Tropidurids (Tropiduris and Plica) had previously been reported in the host range of two oswaldofilarine genera,

Oswaldofilaria and Piratuba, and their parasites assigned to known species described from other groups of lizards.

KEY WORDS: Oswaldofilaria chabaudi n. sp., Filarioidea, Onchocercidae, Oswaldofilariinae, Tropidurus torquatus, Squamata, Tropiduridae, Minas Gerais, Brazil. closely related genus Befilaria, such as the Central American B.

Résumé: OSWALDOFILARIA CHABAUDI N. SP. (NEMATODA: ONCHOCERCIDAE) CHEZ UN LÉZARD SUD-AMÉRICAIN TROPIDURIDAE (SQuamata: Iguania) ET SYNTHĖse Sur LeS OSwaldofilariINAE

Une nouvelle espèce d'Oswaldofilaria est décrite chez Tropidurus torquatus (Tropiduridae: Iguania); la prévalence de la filaire est proche de $30 \%$ et l'intensité moyenne de 3,13 1 2,51 dans l'aire rocheuse de l'étude, Juiz de Fora, Minas Gerais, Brésil. Oswaldofilaria chabaudi $n$. sp. est distinct des treize espèces d'Oswaldofilaria connues en Australie, Afrique et Amérique du Sud par l'oesophage de longueur moyenne, le spicule gauche long de $7 \mathrm{~mm}$ et le rapport spiculaire élevé (proche de 5), l'extrémité caudale ornée dans les deux sexes par une protubérance bifide, et les denticules près des phasmides chez la femelle. Le spicule gauche long et le rapport spiculaire élevé sont des caractères dérivés convergents, observés aussi chez un parasite de crocodile d'Australie, O. kanbaya, et chez plusieurs espèces du genre proche Befilaria, comme B. puertoricensis parasite de Polychrotidae en Amérique Centrale. Oswaldofilaria en Amérique du Sud est représenté par huit espèces parmi lesquelles sont identifiés un groupe primitif avec un œesophage long, parasite d'lguanidae, Polychrotidae (Iguania) et Crocodylidae, et deux groupes évolvés : trois espèces à nombreuses papilles précloacales alignées, parasites de Teiidae (Laterata) et Scincidae (Scincomorpha), et O. chabaudi n. sp. qui n'a pas ce caractère. Des Tropirudidae (Tropidurus et Plica) étaient déjà connus comme hôtes de deux genres d'Oswaldofilariinae, Oswaldofilaria et Piratuba, et leurs parasites identifiés à des espèces décrites dans d'autres groupes de lézards.

MOTS CLÉS : Oswaldofilaria chabaudi n. sp., Filarioidea, Onchocercidae, Oswaldofilariinae, Tropidurus torquatus, Squamata, Tropiduridae, Minas Gerais, Brésil.

\section{INTRODUCTION}

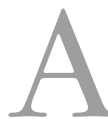

mong onchocercid filarial worms, the subfamily Oswaldofilariinae Chabaud \& Choquet, 1953 is distinct in that the vulva is situated very far from

\footnotetext{
* Universidade Federal de Juiz de Fora, Departamento de Zoologia Laboratório de Instituto de Ciências Biológicas, Laboratório de Taxonomia e Ecologia de Helmintos, Campus Universitário, Martelos, CEP 36036-900, Juiz de Fora, Minas Gerais, Brazil.

*** Universidade Federal do Rio de Janeiro, Instituto de Biofísica Carlos Chagas Filho, Laboratório de Biologia de Helmintos Otto Wuckerer, Cidade Universitária, CEP 21941-901, Rio de Janeiro, Rio de Janeiro, Brazil.

**** Muséum National d'Histoire Naturelle, UMR 7205 CNRS, Parasitologie Comparée, 61, rue Buffon, CP 52, 75231 Paris Cedex 05, France. Correspondence: Sueli de Souza Lima

Tel.: + 553232293218 - Fax: + 553232013216

E-mail: suelisouza.lima@ufff.edu.br
} the head (Chabaud \& Choquet, 1953). A series of other characters suggests that it is not an artificial group: the developed glandular oesophagus, the presence of a buccal capsule, the absence of an area rugosa and a thick tail in the males, and large caudal papillae arranged in a cloacal and a terminal group (Bain, 1974; Anderson $\&$ Bain, 1976). The thirty-two species within the Oswaldofilariinae represent seven genera, two of which are monotypic (Bain et al., 1982). All filariae from Crocodylia and a part of those from Sauria (lizards) belong 
to this subfamily. Oswaldofilaria Travassos, 1933 has a gondwanian-type geographical distribution and is represented by thirteen species, including the four parasitic in crocodilians (Travassos, 1933; Marinkelle, 1981; Bain et al., 1982; Manzanell, 1986). Befilaria Chabaud, Anderson \& Brygoo, 1959 comprises three species in the Ethiopian region (Chabaud et al., 1959; Bain \& Ranque, 1974; Gibbons, 1989) and one in the Neotropical region (Bain \& Chaniotis, 1975). Piratuboides Bain \& Sulahian, 1974 is present in South America and Australia only, with one and two species, respectively [the single African species is not a Piratuboides but a Splendidofilariinae, Madathamugadia huambensis (Petit, Bain, Gomes \& Touratier, 1983) (Bain et al., 1993)]. The remaining four genera have a restricted distribution. Piratuba Lent \& Freitas, 1941 is represented in the Neotropical region by seven species, including the poorlyknown P. mitchelli (Smith, 1910) (Smith, 1910; Lent \& Freitas, 1941; Pelaez \& Perez-Reyes, 1960; Chabaud \& Frank, 1961; Bain, 1974). Conispiculum Pandit, Pandit \& Iyer, 1929, revalidated by Bain et al. (1982) and represented by two species (Castellani \& Willey, 1905; Pandit et al., 1929; Baylis, 1939; Bain et al., 1982), and the monotypic Gonofilaria Mullin, 1973 occur in India (Mullin, 1973). The single species of Solafilaria Chabaud, Anderson \& Brygoo, 1959 is found in Madagascar (Chabaud et al., 1959).

The host range of Oswaldofilariinae and the fact that all filarial species from crocodilians belong to this subfamily, have induced several comments on the probably remote origin of these filariae, with a suggested date as early as the late Jurassic (Bain et al., 1982; Chabaud \& Bain, 1994). It is also supposed that, since that date, they were transmitted by culicids, because the life cycles of modern representatives have all been obtained in mosquitoes: a species of Conispiculum in India (Pandit et al., 1930) and five species of Oswaldofilaria from Australia (Mackerras, 1953) and South America (Prod'hon \& Bain, 1972; Bain \& Chabaud, 1975).

Besides the evolutionary interest of oswaldofilarines, estimation of their specific diversity is another interesting and delicate matter. In this paper we describe a new species found in a Tropiduridae, a family of Iguania already reported in the host range of two genera, Oswaldofilaria and Piratuba. The present finding contrasts with the picture resulting from the rather numerous surveys of oswaldofilarine species parasitising lizards that were conducted in South America. All materials observed during the past thirty years in Brazil (Vicente, 1981; Vicente et al., 1993; Silva \& Kohlsdorf, 2003), Paraguay (Bursey \& Goldberg, 2004) and Peru (Bursey et al., 2005) were assigned to known species. Furthermore, in the Neotropical region, the most recent description was that of a parasite from a crocodylid (Marinkelle, 1981).

\section{MATERIAL AND METHODS}

$\mathrm{F}$ or a survey of its helminth fauna, the lizard Tropidurus torquatus (Wied-Neuwied, 1820) was trapped in an area of rocky outcrops in the vicinity of Toledos, Juiz de Fora, state of Minas Gerais, Brazil $\left(21^{\circ} 48^{\prime} 27.5^{\prime \prime} \mathrm{S} ; 43^{\circ} 35^{\prime} 31.7^{\prime \prime} \mathrm{W}\right)$. This area is characterized by rocky soils, shrubby vegetation and a seasonal climate with dry winters and wet summers. Tie and glue traps were used and captures were made from August 2005 to June 2007, during day light hours. Thirty-eight males (snout-vent length SVL $88.82 \pm 21.23$; range 51.2 $-127.2 \mathrm{~mm}$ ) and 72 females (SVL $75.74 \pm 13.62$; range $42.1-101.4 \mathrm{~mm}$ ) were trapped. Lizards were euthanized, the body cavity was opened by a longitudinal incision from vent to throat and the gastrointestinal tract and other organs were removed. Concerning the localization of the filariae in the lizards, $35 \%$ were found in the body cavity, $65 \%$ in the muscular aponeuroses, of which $58 \%$ in the thighs (equally right and left) and $7 \%$ at the basis of the tail.

Species and authority names follow the Craig Venter reptile database (Venter, 2009). Supra-generic divisions of iguanian lizards follow Frost et al. (2001a, b), while larger phyla in Squamata follow Hedges \& Vidal (2009). Filarial worms were fixed in AFA (95 parts $70 \%$ ethanol, 3 parts $40 \%$ formalin, and 2 parts glacial acetic acid), stored in $70 \%$ ethanol and cleared in lactophenol for examination. The anterior extremity was studied in apical view. The width of the lateral chord was measured in lateral view; attention was given to the presence and/or absence of deirids in several male and female specimens. For detailed studies, samples of microfilariae were extracted from the uterus near the ovijector; the ovijector and spicules were dissected out in one female and one male specimen, respectively. Buccal capsule length is the distance from oesophagus apex to mouth. Oesophagus ratio is oesophagus length/body length given in percent. Spicular ratio is length of left/right spicule. Vulva ratio is the distance vulva to apex/body length as a percentage. Specimens were drawn using a microscope equipped with a camera lucida. Measurements were made on drawings and are given in micrometers, except where otherwise stated.

\section{DESCRIPTION}

\section{OSWALDOFILARIA CHABAUDI N. SP.}

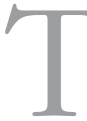
the study is based on 24 females and 24 males. Morphological characters are shown in Figs 1 and 2. Individual measurements of types and a few other specimens, including a young female and a young male, as well as ranges and means in females and males are presented in Table I. 


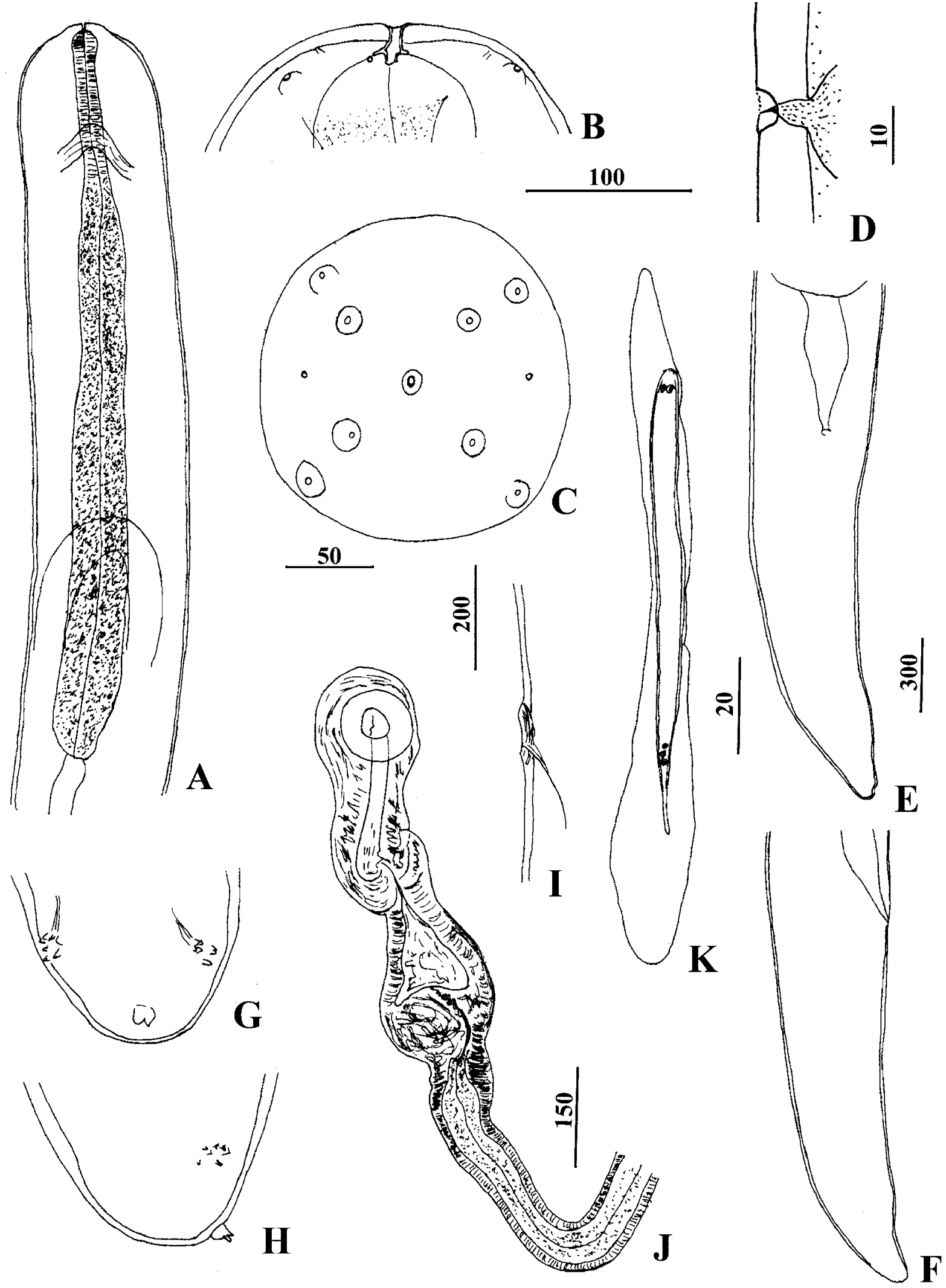

Fig. 1. - Oswaldofilaria chabaudi n. sp. from Tropidurus torquatus. Female. A. Anterior region, dorsoventral view (dotted line indicates extension of uteri). B. Head, lateral view, holotype. C. Head, in front view. D. Deirid, median view. E. \& F. Tail in ventral and right lateral views. G \& H. Caudal extremity in ventral and right lateral views. I. Vulva, lateral view. J. Vagina, ventral view. K. Microfilaria from uteri of a paratype. Scales in $\mu \mathrm{m}$ : A,E,F, 300; B,G,H, 100; C, 50; D, 10; I, 200; J, 150; K, 20. 


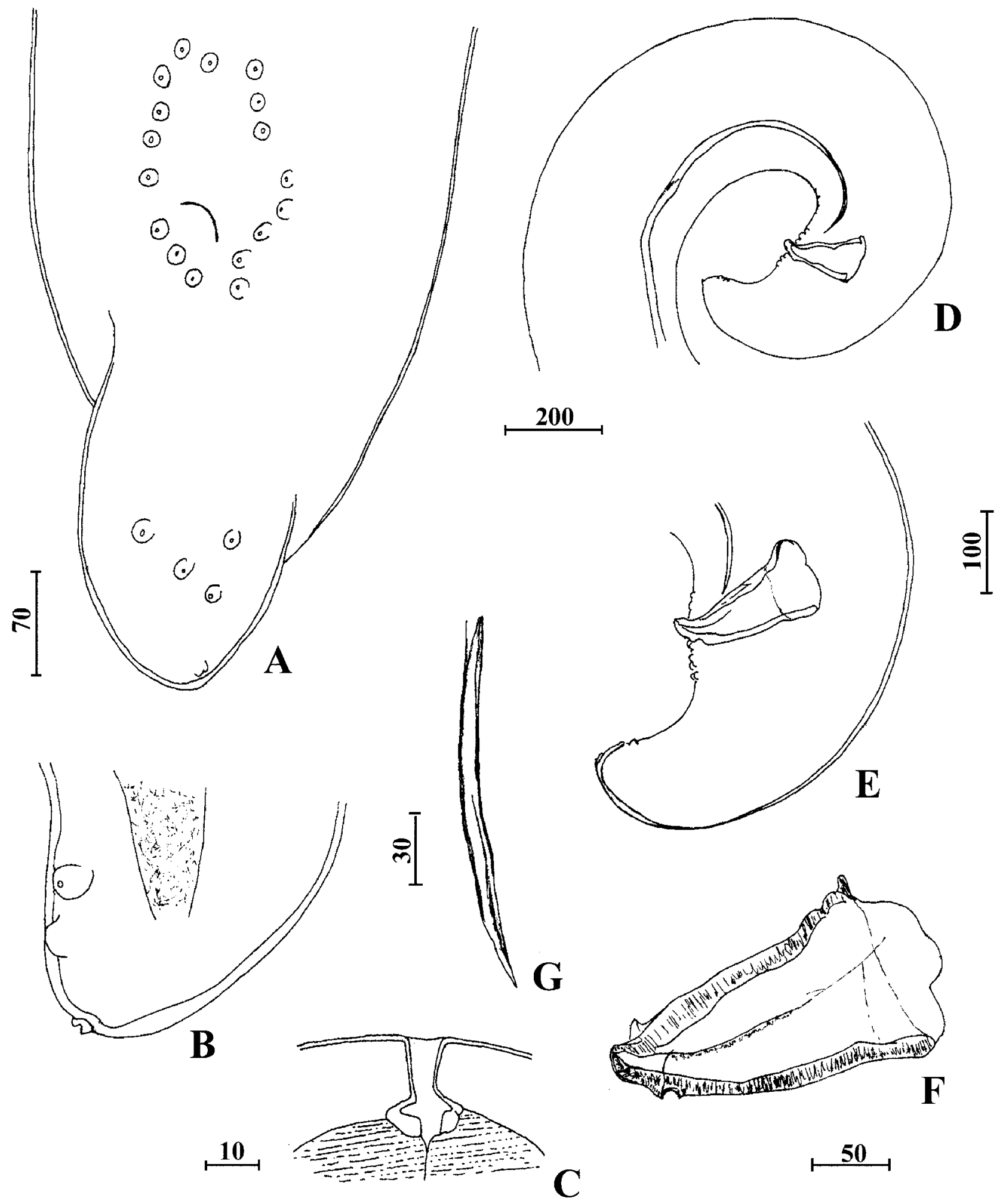

Fig. 2. - Oswaldofilaria chabaudi n. sp. from Tropidurus torquatus. Male. A. Tail, ventral view. B. Extremity of tail, left lateral view. C. Buccal capsule, lateral view, allotype. D. Posterior region and spicules, left lateral view. E. Tail, left lateral view. F. Right spicule, left lateral view. G. Distal extremity of left spicule, left lateral view. Scales in $\mu \mathrm{m}$ : A,B, 70; C, 10; D, 200; E, 100; F, 50; G, 30. 
Type host: Tropidurus torquatus (Wied-Neuwied, 1820) (Tropiduridae: Iguania: Sauria), type host specimen III-1, deposited in "Coleção Herpetológica do Departamento de Zoologia da Universidade Federal de Juiz de Fora", registration number 229.

Type locality: Toledos (21 48' 27.5” S; 43 35' 31.7” W), Juiz de Fora, Minas Gerais, Brazil.

Site: muscular aponeuroses of thighs and base of tail, body cavity.

Type material: female holotype, male allotype and female paratype 109YU; deposited in the Helminth collection of the Muséum National d'Histoire Naturelle (MNHN), Paris.

Other material: recovered from the same host species and locality. One female 102YU, one male 106YU (anterior part), one male and one female $107 \mathrm{YU}$ and one male 108YU, deposited in the Helminth collection of the MNHN, Paris. Other specimens preserved in the Laboratório de Taxonomia e Ecologia de Helmintos, Departamento de Zoologia, Instituto de Ciências Biológicas, Universidade Federal de Juiz de Fora, Brazil. Prevalence and mean intensity: $29.1 \%$ and $3.13 \pm 2.51$.

Body thick. Cuticle thin, slightly thicker laterally. Lateral chords wide, about one third of body width at mid-body.
Anterior region almost as thick as mid-body; extremity subround and, in some specimens, narrowed head (Fig. 1A). Head with four externolabial and four cephalic sublateral papillae, arranged in two squares; amphids tiny (Fig. 1C). Buccal opening small and circular; buccal cavity small, with anterior narrow, thin-walled tube and posterior part shorter and wider, with thicker wall (Figs. 1B, 2C). Deirids tiny, identified in all specimens they were searched for, posterior to beginning of glandular oesophagus (Fig. 1D). Oesophagus clearly divided into short anterior muscular portion and long, thicker glandular portion (Fig. 1A); total oesophagus length shorter in males than females (mean 1,915 and 2,355, respectively), but ratio about three fold higher in males (11\% and $4.14 \%$, respectively; Table I).

In female, genital tract tightly coiled, the most anterior bend reaching level of nerve ring in the larger specimens. Vulva at end of anterior third of body, often on slightly salient plateau ornated with a few circular striae (Fig. 1I); in one specimen a few small scales present on plateau. Vagina large (300 long and 170 wide in holotype) and complex: two chambers separated by sphincter; second chamber more developed and separated from ovijector by strongly muscular sphincter (in holotype, chambers 110 and 160, respectively; Fig. 1J).

\begin{tabular}{|c|c|c|c|c|c|c|c|}
\hline $\begin{array}{c}\text { Female and identification } \\
\text { number }\end{array}$ & $\begin{array}{l}\text { Holotype } \\
109 \text { YU }\end{array}$ & $\begin{array}{c}\text { Paratype } \\
109 \text { YU }\end{array}$ & $102 \mathrm{YU}$ & $105 \mathrm{YU}$ & Young 13.1 & $\begin{array}{c}\text { Mean } \\
(\mathbf{n}=\mathbf{2 3})\end{array}$ & $\begin{array}{c}\text { Range } \\
(n=23)\end{array}$ \\
\hline Length $(\mathrm{mm})$ & 52 & 60 & 72 & 70.5 & 37 & 62.3 & $54.5-77.4$ \\
\hline Width & 500 & 500 & 510 & 650 & 390 & 490 & $430-640$ \\
\hline Buccal capsule length & 19 & 18 & 18 & 20 & 18 & 20 & $18-29$ \\
\hline Nerve ring to head & 425 & 390 & 410 & 430 & 340 & 400 & $380-490$ \\
\hline Deirids to head & $1,300 \& 1,430$ & $950 \& 980$ & $1,090 \& 1,335$ & $1,000 \& \mathrm{ND}$ & ND & ND & ND \\
\hline Total length oesophagus & 2,050 & 2,400 & 2,850 & 2,350 & 2,060 & 2,355 & $1,940-3,000$ \\
\hline Oesophagus ratio (\%) & 3.9 & 4 & 3.9 & 3.3 & 5.5 & 4.14 & $3.2-5.5$ \\
\hline Muscular oesophagus & 350 & 400 & 620 & 510 & 310 & 430 & $300-620$ \\
\hline Vulva to head (mm) & 15.7 & 21.48 & 26.4 & 20.3 & ND & 23.82 & $19.33-27.06$ \\
\hline Vulva ratio (\%) & 30.2 & 35.8 & 36.6 & 28.8 & ND & 34.8 & $28.8-40$ \\
\hline Tail length & 1,000 & 950 & 1,260 & 750 & 650 & 1,130 & $750-1,550$ \\
\hline $\begin{array}{c}\begin{array}{c}\text { Male and identification } \\
\text { number }\end{array} \\
\end{array}$ & $\begin{array}{c}\text { Allotype } 109 \\
\text { YU } \\
\end{array}$ & $106 \mathrm{YU}$ & $108 \mathrm{YU}$ & Young 8.2 & $\begin{array}{c}\text { Mean } \\
(n=23)\end{array}$ & $\begin{array}{c}\text { Range } \\
(n=23)\end{array}$ & \\
\hline Length (mm) & 14 & ND & 16 & 6.79 & 17.8 & $13.83-24.06$ & \\
\hline Width & 265 & 330 & 240 & 260 & 260 & $260-310$ & \\
\hline Buccal capsule length & 16 & ND & 17 & 20 & 15 & $10-20$ & \\
\hline Nerve ring to head & 260 & 250 & 270 & 200 & 220 & $160-270$ & \\
\hline Deirids to head & $600 \& 600$ & $710 \& 790$ & $700 \& 960$ & ND & ND & ND & \\
\hline Total length oesophagus & 1,750 & 2,000 & 1,980 & 1,870 & 1,910 & $1,590-2,350$ & \\
\hline Oesophagus ratio (\%) & 12.5 & ND & 12.3 & 27.5 & 11 & $8.8-13.3$ & \\
\hline Muscular oesophagus & 240 & 400 & 400 & 300 & 350 & $290-490$ & \\
\hline Tail length & 397 & 330 & 380 & 290 & 340 & $300-400$ & \\
\hline Right spicule & 180 & 200 & 240 & 210 & 200 & $190-240$ & \\
\hline Left spicule & 920 & 1,100 & 980 & 1,070 & 960 & $840-1,070$ & \\
\hline Handle left spicule & 350 & 250 & 250 & ND & ND & ND & \\
\hline Spicular ratio & 5.1 & 5.5 & 4.1 & 5.1 & 4,7 & $4-5.15$ & \\
\hline
\end{tabular}

Table I. - Measurements of females and males of Oswaldofilaria chabaudi n. sp. from Tropidurus torquatus.

Young specimens are not included in mean and range. ND: not determined. 
Ovijector tubular, 80-90 wide and 1.8-1.94 mm long, (measured in seven specimens). Posterior body region narrower than anterior part. Tail long, thick and distinctly narrowed in distal region (Fig. 1E, F); phasmidial pores with 5-6 tiny, pointed, tooth-like structures; round extremity ornated with bifurcated projection (Fig. 1G, H).

In male, caudal region spirally coiled (one and half tight turns); thick, short, conical tail, extremity round with bifurcated terminal projection (Fig. 2A, B); area rugosa absent. Total number of caudal papillae: 19 to 22; arranged in two groups; anterior group composed of $7-8$, more or less regularly placed pairs, of which 3 pairs are para- and postcloacal; posterior group composed of two subterminal pairs (Fig. 2A, B). Spicules distinctly unequal and dissimilar; right spicule short, stout, triangular in lateral view, with subterminal transverse circular crest (Fig. 2F); left spicule long, uniformly thin, slightly twisted between handle and lamina (Fig. 2D); distal region of lamina spiraled, with bevelled extemity (Fig. 2G).

Microfilaria short; head with small cephalic hook; thin, anucleated caudal extremity; sheath loose, longer than microfilaria, one extremity more attenuated (Fig. 1K). Measurements ( $\mathrm{n}=20$, from paratype): body 90 (83-93) long, 8 (7-9) wide; cephalic space 8 long; last caudal nucleus 15 from posterior end.

\section{Taxonomic discussion}

A key to the genera of the Oswaldofilariinae was given by Bain et al. (1982) to complete the one published by Anderson \& Bain (1976), which did not include Conispiculum. Our material is compared to the five genera that possess an ovijector with a complex vagina ("sphincter complexe"). Among these genera, Conispiculum and Gonofilaria are excluded because their spicules are subequal (ratio $\leqslant 1.3$ ). Solafilaria, Oswaldofilaria and Befilaria have unequal spicules (ratio $\geqslant 2$ ). Solafilaria is excluded because its vulva is close to the anus, whereas it is in the anterior mid-part of the body in the latter two genera. These are distinguished by the oesophagus length in females, $>2 \mathrm{~mm}$ in Oswaldofilaria, < $1 \mathrm{~mm}$ in Befilaria (Bain, 1974; Bain et al., 1982). The present material has an oesophageal mean length of 2,355 in females, with a single measurement just under 2,000 $(1,940)$, and is, therefore, placed in the genus Oswaldofilaria. It is, however, noted that, while the reference length given for the oesophagus in Befilaria applies well to the two Afromalagasy species (Chabaud et al., 1959; Bain \& Ranque, 1974), it does not comply with the remaining two species; particularly in females of B. puertoricensis Bain \& Chaniotis, 1975 the oesophagus reaches 1,335 in length (Bain \& Chaniotis, 1975). The validity of the closely related genera Oswaldofilaria and Befilaria is questionable.
The following thirteen species of Oswaldofilaria are currently recognized (Table II):

- In Australia five species: O. kanbaya Manzanell, 1986 from a crocodile (Crocodylus porosus Schneider, 1801), the others from two species of Agamidae, O. chlamydosauri (Breinl, 1913) (type-host Chlamydosaurus kingii Gray, 1825), O. innisfailensis (Mackerras, 1962), O. pflugfelderi (Frank, 1964) (both transfered in the genus by Bain \& Sulahian, 1974), O. samfordensis Manzanell, 1982 [type-host of the last three species is Physignatus lesueurii (Gray, 1831)].

- In Africa O. versterae Bain, Kouyaté \& Baker, 1982 from Cr. niloticus Laurenti, 1768.

- In South America seven species: one Colombian, O. medemi Marinkelle, 1981 from a crocodile [Paleosuchus trigonatus (Schneider, 1801)]; six Brazilian species, O. bacillaris (Molin, 1858) also from a crocodile (Caiman crocodilus Linnaeus, 1758); O. brevicaudata (Rodhain \& Vuylsteke, 1937) from an iguanid [Iguana iguana (Linnaeus, 1758)], O. azevedoi Bain, 1974 from a polychrotid [type-host Polychrus marmoratus (Linnaeus, 1758)]; two species from teiids, O. petersi Bain \& Sulahian, 1974 [type-host Tupinambis teguixin (Linnaeus, 1758)], O. belemensis Bain \& Sulahian, 1974 (type-host Dracaena guianensis Daudin, 1802); and O. spinosa Bain \& Sulahian, 1974 from a scincid [type-host Mabuya mabouya (Bonnaterre, 1789)]. All these species (Table II) are distinct from the present material by many characters, of which only the most obvious are reported below.

As a general remark on the species of Oswaldofilaria, the oesophagus is longer, rarely equal but never shorter in females than in males, and the oesophagus ratio is higher in males, rarely equal in both sexes (Table II).

Six species are distinct from the new species in having a longer oesophagus. In O. versterae, it is 4,730 long in the male and the oesophagus ratio is $16.3 \%$ vs 1,590 2,350 long and 8.8-13.3\% in our material; no data are available on the female. In $O$. bacillaris (redescribed by Prod'hon \& Bain, 1972), O. medemi, O. kanbaya, O. brevicaudata (redescribed by Bain \& Sulahian, 1974) and $O$. azevedo $i$, the oesophagus is $\geqslant 3,340$ in the female and the ratio $\geqslant 10 \%$ (not known in $O$. azevedo $i$ ) vs 1,940-3,000 long and ratio 3.2-5.5\% in our females; in the male of these species the oesophagus is $\geqslant 2,400$. These species also have a tail length $<500$ in the female. In addition, in the first four species, which are parasitic in crocodiles, no more than three to four pairs of preand paracloacal papillae are present and these are regularly aligned; the spicular ratio does not exceed 4, except in O. kanbaya. Other distinctive characters are listed for each species: $O$. versterae has a twice longer right spicule than the present material (Bain et al., 1982); in $O$. bacillaris the mouth and buccal capsule are oriented dorsally (Prod'hon \& Bain, 1972); O. medemi has the longest oesophagus (13,000 in females, 6,100 in males), 
the tip of its left spicule is lanceolated, the right spicule is twice shorter than in O. chabaudi, and the tip of the tail is smooth in both sexes (Marinkelle, 1981); O. kanbaya has two phasmidial conical lappets in the tail of both females and males, a right spicule without a subterminal crest and a round extremity, as well as longer microfilariae (170 vs 83-93) (Manzanell, 1986); O. brevicaudata has no spines, or projections on the tail in both sexes and the microfilaria is 140-160 long; in O. azevedo $i$ the distal extremity of the left spicule is a folded membrane (Bain, 1974).

In the remaining seven species the oesophagus length and ratio is similar to our specimens. However, their spicular ratio does not exceed 3. The Oswaldofilaria chlamydosauri female (redescribed by Manzanell,1982), has a long tail (700) as seen in our specimens, but the male possesses a distinctly attenuated tail, a gubernaculum, and the left spicule has a membranous extremity; the buccal cavity is flattened laterally and deirids are absent in both sexes. In the other species, the female tail does not exceed 550. Oswaldofilaria petersi, O. belemensis and O. spinosa have several additional pairs of regularly aligned pre-cloacal papillae; head papillae are arranged in a laterally streched rectangle; in addition, in the first two species, the body cuticle is ornated with transverse bands of longitudinal crests, whereas the female tail of the third species has two terminal cushions covered with points (Bain \& Sulahian, 1974). Oswaldofilaria samfordensis is large, with a long buccal capsule, 40 to 100 (mean 50) in females and 30 in males (Manzanell, 1982). In O. pflugfelderi, of which the specific validity was confirmed by Manzanell (1982), the tail extremity of both sexes is devoid of spines or projections, and the microfilariae are longer (150 vs 83-93), with a tight sheath and refringent granules (Frank, 1964). Oswaldofilaria innisfailensis is unique in that its vulva is slightly posterior to the oesophageal-intestinal junction $(3.9 \mathrm{~mm}$ from head, vulva ratio $5 \%$; Mackerras, 1962) and microfilariae are 126 long (Manzanell, 1982). Finally, none of the known Oswaldofilaria species have a vagina that is composed of two chambers.

We conclude that the material parasitic in Tropidurus torquatus from Brazil is a new species, Oswaldofilaria chabaudi, named in honour of Alain Gabriel Chabaud for his dedication to science and his invaluable scientific contribution to the field of Helminthology.

\section{GENERAL DISCUSSION}

T he new species, O. chabaudi n. sp., is easily characterized by the caudal bifurcated projection in both sexes, the long female tail, bearing toothlike structures near the phasmids, the thin left spicule that is about $1 \mathrm{~mm}$ long, a spicular ratio ranging from
4 to 5.15 , a vagina with two chambers, and a middlesized oesophagus.

When considering the affinities of the new species, it is seen that O. kanbaya, a parasite of Crocodylidae in Australia, also has a long, thin left spicule and a spicular ratio of 5 , as do several species of Befilaria, including the Neotropical representative, B. puertoricensis. These similarities seem to result from homoplasy, because $O$. kanbaya possesses a long oesophagus, Befilaria a short one and that of O. chabaudi n. sp. is of intermediate size. In filarioid nematodes, a phyletic value is given to oesophagus dimensions: a large oesophagus with a well-developed glandular part is a primitive character that is observed in all infective larvae of Onchocercidae ( $c f$ Bain \& Chabaud, 1986). In the infective larvae of Oswaldofilaria, the oesophagus ratio ranges from 32 to $59 \%$; later, in the host, there is a tendency to reduce the digestive tract, linked to the tissular habitat of these parasites, and a short oesophagus is considered a derived character. Befilaria is very close to Oswaldofilaria, but is retained because of the smaller oesophagus size; however, the length limit is $\leqslant 1,400$ in females instead of 1,000 as reported previously (Bain et al., 1982). In the genus Oswaldofilaria, species parasitic in Crocodylidae from Africa (Bain et al., 1982), South America (Travassos, 1933; Marinkelle, 1981) and Australia (Manzanell, 1986) all have a long oesophagus and can be considered primitive (Table II).

In Australia, as underlined by Manzanell (1986), the single Oswaldofilaria from a crocodile is well distinct from the four species parasitic in Agamidae. The male oesophagus of the latter is less than 2,500 long, and some of them have additional derived characters, such as the laterally flattened buccal capsule and a gubernaculum in O. chlamydosauri; the left spicule is transformed into a tube in the distal half in O. samfordensis (cf. Manzanell, 1982), and in O. innisfailensis the vulva is anterior. This is not the case in South America, where two species from iguanid and polychrotid lizards, $O$. brevicaudata and $O$. azevedo $i$, respectively, have a long oesophagus, deirids, head papillae that are arranged in a square, and cannot be opposed to species parasitic in crocodiles. This resemblance, which contrasts with the host groups, suggested that Oswaldofilaria had diversified at an epoch when Saurians and Crocodylidae were both present and not geographically dispersed, that is before the break-up of Gondwana, about $150 \mathrm{MY}$ ago (Hedges \& Vidal, 2009). Indeed, the infective larvae of Oswaldofilaria spp. from a crocodile and from diverse lizards have a very peculiar character in common, which is the presence of longitudinal cuticular crests on their body (Bain \& Chabaud, 1986).

Considering the present data, the Neotropical region displays the highest diversity of Oswaldofilaria parasitic in Sauria (Vicente et al.,1993; Silva \& Kohlsdorf, 2003; 


\begin{tabular}{|c|c|c|c|c|c|c|c|c|}
\hline Oswaldofilaria species & chabaudi & & & versterae & kanbaya & medemi & brevic & data \\
\hline Authority parasite name & n. sp. & (Mc & 858) & $\begin{array}{c}\text { Bain, } \\
\text { Kouyaté \& } \\
\text { Baker, } 1982\end{array}$ & $\begin{array}{l}\text { Manzanell, } \\
1986\end{array}$ & $\begin{array}{c}\text { Marinkelle, } \\
1981\end{array}$ & $\begin{array}{r}\text { (Rod } \\
\text { Vuylste }\end{array}$ & $\begin{array}{l}\text { in \& } \\
, 1937)\end{array}$ \\
\hline Female & Holotype & $\circ$ & $*$ & Type & Allotype & Allotype & $* *$ & $* * *$ \\
\hline Length (mm) & 52 & 45 & 64 & $\mathrm{X}$ & 31 & 49 & $37.6-42.8$ & 17.3 \\
\hline Width at mid-body & 500 & 250 & 375 & 510 & 250 & 250 & $447-500$ & 270 \\
\hline Buccal capsule length & 19 & 15 & 14 & $\mathrm{X}$ & 20 & 16 & 16 & 6 \\
\hline Nerve ring to head & 425 & 600 & 330 & $\mathrm{X}$ & ND & 425 & & 240 \\
\hline Deirids to head & $1,300 \& 1,430$ & ND & 1,250 & $\mathrm{X}$ & absent & $?$ & & absent \\
\hline Oesophagus length & 2,050 & 9,000 & 4,800 & $\mathrm{X}$ & 3,500 & 13,000 & $4,140-4,220$ & 3,340 \\
\hline Oesophagus ratio (\%) & 3.9 & 30 & 10 & $\mathrm{X}$ & 11.2 & 26.5 & $9.8-11.1$ & 19.3 \\
\hline Muscular oesophagus & 350 & 1,000 & ND & $\mathrm{X}$ & 500 & 535 & $456-560$ & 290 \\
\hline Vulva to head (mm) & 15.7 & $13-21$ & 12.8 & $\mathrm{X}$ & 9.2 & 16.8 & 12.7 & 6.6 \\
\hline Vulva ratio (\%) & 30.1 & 28 & 20 & $\mathrm{X}$ & 29 & 34 & 33 & 38 \\
\hline Tail length & 1,000 & 350 & 435 & 300 & 320 & 296 & $352-408$ & 395 \\
\hline Male & Allotype & $\circ$ & $*$ & Type & Holotype & Holotype & $* *$ & $* * *$ \\
\hline Length (mm) & 14 & 20 & 31.8 & 29 & 18 & 24 & $16-18$ & 6.6 \\
\hline Width & 265 & 210 & 310 & 240 & 150 & 200 & $171-210$ & 150 \\
\hline Buccal capsule length & 16 & 8 & 10 & 15 & 15 & 12 & 16 & ND \\
\hline Nerve ring to head & 260 & 360 & 525 & 250 & $350^{1}$ & 298 & & \\
\hline Deirids to head & 600 & ND & 875 & 600 & absent & $?$ & & \\
\hline Oesophagus length & 1,750 & 5,300 & 3,585 & 4,730 & 3,200 & 6,100 & $2,810-3,210$ & 2,400 \\
\hline Oesophagus ratio (\%) & 12.5 & 26.5 & 11.25 & 16.3 & 17.7 & 25.4 & 17.5 & 36.6 \\
\hline Muscular oesophagus & 240 & 650 & 575 & 330 & 400 & 238 & $367-436$ & ND \\
\hline Tail length & 397 & 140 & 265 & 330 & 180 & 154 & $160-200$ & 160 \\
\hline Right spicule & 180 & 180 & 160 & 450 & 110 & 92 & $136-160$ & 135 \\
\hline Left spicule & 920 & 380 & 450 & 870 & 550 & 366 & $296-312$ & 220 \\
\hline Spicular ratio (left/right) & 5.1 & 2.1 & 2.8 & 1.93 & 5 & 3.9 & 1.95 & 1.7 \\
\hline Microfilaria $^{2}$ & & $\circ$ & $*$ & & & & $* *$ & $* * *$ \\
\hline Length & $89-93$ & ND & $84-117$ & $95-102$ & 170 & $86-92$ & ND & $140-160$ \\
\hline Width & $7-9$ & ND & $6-9$ & 6 & $6.5-7$ & $5.3-5.4$ & ND & 7 \\
\hline $\begin{array}{l}\text { Host genus } \\
\text { Host species }\end{array}$ & $\begin{array}{l}\text { Tropidurus } \\
\text { torquatus }\end{array}$ & & & $\begin{array}{l}\text { Crocodylus } \\
\text { niloticus }\end{array}$ & $\begin{array}{l}\text { Crocodylus } \\
\text { porosus }\end{array}$ & $\begin{array}{c}\text { Paleosuchus } \\
\text { trigonatus }\end{array}$ & $\begin{array}{l}\operatorname{Ig} u \\
\operatorname{ig} u\end{array}$ & \\
\hline Authority host name & $\begin{array}{l}\text { (Wied- } \\
\text { Neuwied, } \\
1820)\end{array}$ & Linn & 1758 & $\begin{array}{l}\text { Laurenti, } \\
1768\end{array}$ & $\begin{array}{c}\text { Schneider, } \\
1801\end{array}$ & $\begin{array}{l}\text { (Schneider, } \\
\text { 1801) }\end{array}$ & (Linnae & 1758) \\
\hline Host family & Tropiduridae & $\mathrm{CrO}$ & idae & Crocodylidae & Crocodylidae & Crocodylidae & Igua & dae \\
\hline Country & Brazil & & & Africa & Australia & Colombia & $\mathrm{Br}$ & \\
\hline Main location in host & $\begin{array}{c}\text { Aponeuroses, } \\
\text { body cavity }\end{array}$ & Apc & oses & ND & Peritoneum & $\begin{array}{c}\text { Thoracic } \\
\text { wall }\end{array}$ & Dorsal p & toneum \\
\hline
\end{tabular}

- In Travassos (1933). * In Prod'hon \& Bain (1972). ** In Freitas \& Lent (1937). ${ }^{* * *}$ In Bain (1974) (measurements of Rodhain \& Vuylsteke are close to those of Bain and not reported). ${ }^{* * * *}$ In Manzanell (1982). ND: not determined. X: not measurable because worm not complete. ?: not searched. ${ }^{1}$ : measured on the figure.

2 : From blood or uterus; ND: not determined.

Table II. - The fourteen species of Oswaldofilaria, including O. chabaudi n. sp. Species are presented according to the order used in the discussion. Unless otherwise specified, the authorities of parasite names match the reference. 
azevedo $i$

Bain, 1974

spinosa

petersi

belemensis

pflugfelderi innisfailensis

chlamydosauri samfordensis

Bain \& $\quad$ Bain \& $\quad$ Bain \& Sulahian, 1974 Sulahian, 1974 Sulahian, 1974

(Frank, 1964) (Mackerras, 1962) (Breinl, 1913) Manzanell, 1982

Type

$\mathrm{X}$

520

ND

760

$1,160 \& 1,570$

3,720

$\mathrm{X}$

800

15.8

$\mathrm{X}$

490

Type

21.5

290

13

420

$805 \& 870$

2,400

11.2

410

250

190

400

2.1

Type
34
380
13
220

Type
64
450
17
380

Type
115
450
25
350
$?$
2,300
2
360
27
23
480

$\begin{array}{cc}\text { Paratype (range) } & \text { A female } \\ 77 & 68 \\ 500 & 330 \\ 15 & \text { ND } \\ 420 & \text { ND } \\ ? & ? \\ 2,800 & 2,600 \\ 4.5 & 3.8 \\ 580 & 600 \\ 18 & 3.9 \\ 25(23-38) & 5 \\ 550 & 390\end{array}$

Type
63
375
20
320

Holotype
27
255
25
380

?

270

$$
1,140
$$

$$
7
$$$$
280
$$$$
260
$$

98

298

3.1

Type
26.2
260
17
300

?

1,750

7

380

160

90

380

3.1
$?$
2,310

$$
3.6
$$$$
380
$$$$
260
$$

180

465

2.58

1,774

6.5

374

120

115

280

2.4
A male

20
230
ND
ND

?

1,770

8.8

350

210

155

320

2
**** (range)

$\begin{array}{ll}64 & 121 \\ 450 & 560\end{array}$

$50(25-50)$

50 (40-100)

5,501

absent

2,300

3.6

700

25.6

40

700

4,001

present

2,600

2.1

600

43.56

36

520

Holotype

52

370

30

310

absent

present

2,000

2,000

6.8

3.8

500

500

360

170

\begin{tabular}{|c|c|c|c|c|c|c|c|}
\hline $180-192$ & 58 & $58-62$ & $68-78$ & 150 & $126^{* * * *}$ & $110-122$ & 83 \\
\hline 7 & 4 & 9 & $9 / 9.5$ & ND & ND & 6.5 & 7.7 \\
\hline $\begin{array}{l}\text { Polychrus } \\
\text { marmoratus }\end{array}$ & $\begin{array}{l}\text { Mabuya } \\
\text { mabouya }\end{array}$ & $\begin{array}{l}\text { Tupinambis } \\
\text { teguixin }\end{array}$ & $\begin{array}{l}\text { Dracaena } \\
\text { guianensis }\end{array}$ & $\begin{array}{c}\text { Pbysignatus } \\
\text { lesueurii }\end{array}$ & $\begin{array}{l}\text { Physignatus } \\
\text { lesueurii }\end{array}$ & $\begin{array}{c}\text { Chlamydosaurus } \\
\text { kingii }\end{array}$ & $\begin{array}{c}\text { Physignatus } \\
\text { lesueurii }\end{array}$ \\
\hline $\begin{array}{l}\text { (Linnaeus, } \\
\text { 1758) }\end{array}$ & $\begin{array}{c}\text { (Bonnaterre, } \\
1789)\end{array}$ & $\begin{array}{l}\text { (Linnaeus, } \\
\text { 1758) }\end{array}$ & Daudin, 1802 & (Gray, 1831) & (Gray, 1831) & Gray, 1825 & (Gray, 1831) \\
\hline $\begin{array}{c}\text { Polychrotidae } \\
\text { Brazil }\end{array}$ & $\begin{array}{l}\text { Scincidae } \\
\text { Brazil }\end{array}$ & $\begin{array}{l}\text { Teiidae } \\
\text { Brazil }\end{array}$ & $\begin{array}{l}\text { Teiidae } \\
\text { Brazil }\end{array}$ & $\begin{array}{l}\text { Agamidae } \\
\text { Australia }\end{array}$ & $\begin{array}{l}\text { Agamidae } \\
\text { Australia }\end{array}$ & $\begin{array}{l}\text { Agamidae } \\
\text { Australia }\end{array}$ & $\begin{array}{l}\text { Agamidae } \\
\text { Australia }\end{array}$ \\
\hline Body cavity & $\begin{array}{l}\text { Armpit, spinal } \\
\text { aponeuroses }\end{array}$ & $\begin{array}{c}\text { Peritoneum } \\
\text { Intestinal wall }\end{array}$ & $\begin{array}{c}\text { Heart \& large } \\
\text { vessels }\end{array}$ & Aponeuroses & $\begin{array}{l}\text { Subperitoneal } \\
\text { tissue }\end{array}$ & $\begin{array}{l}\text { Peritoneum } \\
\text { Aponeuroses }\end{array}$ & $\begin{array}{r}\text { Peritoneum } \\
\text { Aponeuroses }\end{array}$ \\
\hline
\end{tabular}

370

2.1 
Bursey \& Goldberg, 2004; Bursey et al., 2005). The six Oswaldofilaria species represent three morphological groups which are not related to the host groups. These are in Iguania, the primitive $O$. brevicaudata and $O$. azevedo $i$, parasitic in Iguanidae and Polychrotidae, respectively; the derived O. chabaudi n. sp. from Tropiduridae; in other Sauria, the three last species with distinct derived characters (numerous and aligned precloacal papillae, head papillae arranged in a rectangle), Oswaldofilaria spinosa parasitic in Scincidae (Scincomorpha), O. petersi and O. belemensis from Teiidae (Laterata),

When taking only the original descriptions into account, the absence of congruence between host groups and parasite species appears obvious among the South American Oswaldofilaria spp. This is reinforced when further reports are referred to. To take a recent example, the host range and geographic distribution of two species that were originally found in the Amazonian region of Belem, Para, Brazil, have been extended: O. azevedo $i$ described from Polychrus marmoratus (Polychrotidae) was reported from a tropidurid, Plica umbra Linnaeus, 1758, in the western part of the Amazonian basin in Peru, at Reserva Cuzco Amazonica (Bursey et al., 2005); O. petersi, described from the teiid Tupinambis teguixin, was reported in Tropidurus hispidus Spix, 1825 in Bahia, Brazil (Silva \& Kohlsdorf, 2003), but in this case the identification seems doubtful, because the typical numerous precloacal, aligned papillae are not figured and a gubernaculum is reported.

Parasite host lists are considerable work and of great importance in extending our knowledge on the distribution of nematodes. However, recent studies on diverse groups, such as Rhabdiasidae from lizards (Lhermitte-Vallarino et al., 2009) and anurans (Junker et al., 2010), as well as Seuratidae (Lhermitte-Vallarino et al., 2007) or trichostongylids (Durette-Desset, 2006) from lizards suggest that species identifications should be taken with caution. In the case of filariae, the microfilaria is an important discriminative character (Esslinger, 1987, to cite only one example), the study of which is, however, often ommitted. The exact degree of diversity is difficult to estimate, but in general it proved to be higher than expected and, in the cited recent works, morphological and molecular analyses were congruent when both were performed. Consequently host specificity and the notion of generalist parasites attributed sometimes to parasites of cold-blooded hosts (Bursey et al., 2005) are difficult to assess.

Since the prevalence of $O$. chabaudi n. sp. is close to $30 \%$ in T. torquatus, a common lizard in Juiz de Fora area, it seems possible to further the investigation on this oswaldofilarine, by elucidating its life cycle and larval morphology; we expect a culicid vector and an infective larva with longitudinal crests. The species is also important when considering mutualistic relationships with the endobacterial Wolbachia and its evolutionary history (Casiraghi et al., 2005; Fenn et al., 2006). Interestingly, to date, the few filarial species from Lissamphibians and Squamata that have been studied do not harbour Wolbachia (Casiraghi et al., 2004; Bain et al., 2008), contrary to many species parasitic in mammals. It should be noted, however, that Wolbachia presence was investigated in a single Oswaldofilariinae only, belonging to the genus Piratuba.

\section{ACKNOWLEDGEMENTS}

Thank Samuel Campos Gomide and Berna-
dete Maria de Sousa, who identified the
lizards.

\section{REFERENCES}

Anderson R.C \& Bain O. Diplotriaenoidea, Aproctoidea and Filarioidea, in: Keys to the Nematode Parasites of Vertebrates. Roy C. Anderson, Alain G. Chabaud \& Sheila S. Willmott (eds), Farnham Royal, 1976, Archival volume, 2009, n 14 Spirurida, 391-448.

BaIn O. Description de nouvelles filaires Oswaldofilariinae de lézards sud-américains; hypothèse sur l'évolution des filaires de reptiles. Bulletin du Muséum National d'Histoire Naturelle, Paris, 1974, 138, 169-200.

Bain O. \& Chabaud A.G. Développement chez des moustiques de trois filaires de lézards sud-américains du genre Oswaldofilaria. Annales de Parasitologie Humaine et Comparée, 1975, 50, 209-221.

Bain O. \& Chabaud A.G. Atlas des larves infestantes de Filaires. Tropical Medicine and Parasitology, 1986, 37, 301-340.

Bain O. \& Chaniotis B.N. Befilaria puertoricensis n. sp. nouvelle Filaire Oswaldofilariinae d'Iguanidae aux Caraïbes (Puerto Rico). Bulletin du Muséum National d'Histoire Naturelle, Paris, 1975, 3e sér., 281, Zoologie, 191, 1-5.

Bain O. \& RANQue P. Une nouvelle Filaire de lézard, Befilaria africana n. sp.; appartenance de ce genre aux Oswaldofilariinae. Bulletin du Muséum National d'Histoire Naturelle, $3^{\text {e }}$ sér., 208, 1974, Zoologie, 138, 159-167.

Bain O. \& Sulahian A. Trois nouvelles filaires du genre Oswaldofilaria chez des lézards sud-américains; essai de classification des Oswaldofilariinae. Bulletin du Muséum National d'Histoire Naturelle, 1974, 156, 827-841.

Bain O., Kouyaté J. \& Baker M. Nouvelles données sur les Oswaldofilariinae (Filarioidea, Nematoda). Bulletin $d u$ Muséum National d'Histoire Naturelle, 1982, 1-2, 61-69.

Bain O., Casiraghi M., Martin C. \& Uni S. The Nematoda Filarioidea: critical analysis linking molecular and traditional approaches. Parasite, 2008, 15, 342-348.

Bain O., Wanji S., Petit G., Paperna I. \& Finkelman S. Filaires Splendidofilariinae de lézards: nouvelles espèces, redes- 
cription, cycle chez phlébotome. Systematic Parasitology, 1993, 26, 97-115.

BaYlis H.A. The fauna of British India, including Ceylon and Burma. Nematoda. Vol II (Filarioida, Dioctophymoidea and Trichinelloidea). Taylor and Francis, Ltd, London, 1939, $274 \mathrm{p}$.

Bursey C.R. \& Goldberg S.R. Helminths of Tropidurus guarani (Sauria: Tropiduridae) from Paraguai. Comparative Parasitology, 2004, 71, 203-207.

Bursey C.R., Goldberg S.R. \& PARMeleE J.R. Gastrointestinal helminths from 13 species of lizards from Reserva Cuzco Amazònico, Peru. Comparative Parasitology, 2005, 72, 50-68.

Casiraghi M., Bain O., Guerrero R., Martin C., Pocacqua V., GARDNER S.L., FrANCESCHI A. \& BANDI C. Mapping the presence of Wolbachia pipientis on the phylogeny of filarial nematodes: evidence for symbiont loss during evolution. International Journal of Parasitology, 2004, 34, 191-203.

Casiraghi M., Bordenstein S.R., Baldo L., Lo N., Beninati T., Wernegreen J.J., Werren J.H. \& Bandi C. Phylogeny of Wolbachia pipientis based on gltA, groEL and ftsZ gene sequences: clustering of arthropod and nematode symbionts in the F supergroup, and evidence for further diversity in the Wolbachia tree. Microbiology, 2005, 151, 4015- 4022 .

Castellani A. \& Willey A. Observations on Haematozoa in Ceylon. Quarterly Journal of Microscopical Science, 1905, 49, 383-402.

Chabaud A.G. \& Bain O. The evolutionary expansion of the Spirurida. International Journal for Parasitology, 1994, 24, 1179-1201.

Chabaud A.G. \& Choquet M.T. Nouvel essai de classification des Filaires (superfamille des Filarioidea). Annales de Parasitologie Humaine et Comparée, 1953, 28, 172-192.

Chabaud A.G. \& Frank W. Les Filaires de l'Héloderme (Note additive). Annales de Parasitologie Humaine et Comparée, 1961, 36, 804-805.

Chabaud A.G., Anderson R.C. \& Brygoo E.R. Cinq Filaires de Reptiles malgaches. Mémoires de l'Institut Scientifique de Madagascar, 1959, sér. A, 13, 103-126.

Durette-Desset M.-C., Anjos L.A. \& Vrcibradic D. Three new species of the genus Oswaldocruzia Travassos, 1917 (Nematoda, Trichostrongylina, Molineoidea) parasites of Enyalius spp. (Iguanidae) from Brazil. Parasite, 2006, 13, 115-125.

ESSLINGER J.H. Ochoterenella figueroai sp. n. and O. lamothei sp. n. (Nematoda: Filarioidea) from the toad Bufo marinus. Proceedings Helminthological Society Washington, 1987, 54, 126-132.

Fenn K., Conlon C., Jones M., Ouail M.A., Parkhill J. \& Blaxter M. Phylogenetic relationships of the Wolbachia of nematodes and arthropods. PLoS Pathogens, 2006, 3, e94.

FRANK W. Neubeschreibung einer Filarie, Macdonaldius pflugfelderi n. spec. (Nematoden, Filarioidea) aus der Muskulatur der Wasseragame, Physignathus lesueurii (Gray) (Reptilia, Agamidae). Zeitschrift für Parasitenkunde, 1964, 24, 442-452.

Freitas J.F.T. \& LENT H. Sobre Oswaldofilaria brevicaudata (Rhodain \& Vuylsteke, 1937) n. comb. (Nematoda:
Filarioidea). Memórias do Instituto Oswaldo Cruz, 1937, 32, 439-442.

Frost D.R., Etheridge R., Janies D. \& Titus T.A. Total evidence, sequence aligment, evolution of Polychrotidae lizards and a reclassification of the Iguania (Squamata, Iguania). American Museum Novitates, 2001a, 3343, 1-38.

Frost D.R., Rodrigues M.T., Grant T. \& Titus T.A. Phylogenetics of the lizard genus Tropidurus (Squamata: Tropiduridae: Tropidurinae): direct optimization, descriptive efficiency, and sensitivity analysis of congruence between molecular data and morphology. Molecular Phylogenetics and Evolution, 2001b, 21, 352-371.

GibBons L.M. Befilaria pseudocordyli n. sp. (Nematoda, Filarioidea) from the small-scaled girdled lizard, Pseudocordylus microlepidotus. Journal de Zoologie Africaine, 1989, 103, 35-39.

HEDGEs S.B. \& VIDAL N. Lizards, snakes and amphisbaenians (Squamata), in: The Timetree of Life. Hedges S.B. \& Kumar S. (eds), Oxford University Press, 2009, 383-389.

Junker K., Lhermitte-Vallarino N., Barbuto M., Ineich I., Wanji S. \& Bain O. New species of Rhabdias (Nematoda, Rhabdiasidae) from Afrotropical anurans, including molecular evidence and notes on biology. Folia Parasitologica, 2010, 57, 47-61.

LENT H. \& Freitas J.F.T. Sobre os filarídeos parasitos de lacertideos neotropicos. Revista Brasileira de Biologia, 1941, 1, 383-386.

Lhermitte N., Bain O. \& Hering-Hagenbeck S. Three species of Skrjabinelazia (Nematoda: Seuratidae) parasite of Geckonidae and Lacertidae from South Africa, Europe and Australia. Systematic Parasitology, 2007, 67, 125-137.

Lhermitte-Vallarino N., Barbuto M., Junker K., Boistel R., INEICH I., WanjI S. \& BaIN O. Rhabdias rhampholeonis n. sp. and Rhabdias mariauxi n. sp. (Nematoda, Rhabdiasoidea), first lung worms from leaf chameleons: description, molecular evidence and notes on biology. Parasitology International, 2009, 58, 375-83.

MACKERRAS M.J. Lizard filaria: transmission by mosquitoes of Oswaldofilaria chlamydosauri (Breinl) (Nematoda: Filarioidea). Parasitology, 1953, 43, 1-3.

MACKERRAS M.J. Filarial parasites (Nematoda: Filarioidea) of Australian animals. Australian Journal of Zoology, 1962, 10, 400-457.

ManZanell R. Oswaldofilaria spp. (Filarioidea, Nematoda) in Australian agamid lizards, with a description of a new species and a redescription of $O$. chlamydosauri (Breinl). Annales de Parasitologie Humaine E Comparée, 1982, 57, $27-143$.

ManzANELl R. Oswaldofilaria kanbaya n. sp., a new filarioid worm (Nematoda, Filarioidea). Annales de Parasitologie Humaine E Comparée, 1986, 61, 245-254.

Marinkelle C.J. Oswaldofilaria medemi n. sp. (Nematoda: Filarioidea), from the smooth-fronted caiman, Paleosuchus trigonatus from Colombia. Revista de Biologia Tropical, 1981, 29, 5-10.

Mullin S.W. Gonofilaria rudnicki gen. et sp. n. (Nematoda: Filarioidea) from Malaysian lizards. Proceedings of the Helminthological Society of Washington, 1973, 40, 282-285. 
Pandit C.G., Pandit S.R. \& Iyer P.V.S. A new filarid in Calotes versicolor: Conispiculum guindiensis n. g., n. sp. Indian Journal of Medical Research, 1929, 16, 954-958.

PANDit C.G., PANDit S.R. \& Iyer P.V.S. The development of the Filaria Conispiculum guindiensis (1929) in C.fatigans, with a note on the transmission of the infection. Indian Journal of Medical Research, 1930, 17, 421-429.

Pelaez D. \& Perez-Reyes R. Piratuba lanceolata nov. sp., parasite de la Lagartija Sceloporus teapensis Günther, 1890 (Nemat. Filar.). Revista Latinoamericana de Microbiologia, 1960, 3, 67-73.

Petit G., Bain O., Gomes A. F. \& Touratier L. Piratuboides buambensis n. sp., filaire Oswaldofilariinae parasite de lézards en Afrique australe. Bulletin de Muséum National d'Histoire Naturelle, Paris, 1983, $4^{\mathrm{ème}}$ série, 5, section A, no. 3, 743-747.

Prod'hon J. \& Bain O. Développement larvaire chez Anopheles stephensi d'Oswaldofilaria bacillaris. Annales de Parasitologie Humaine et Comparée, 1972, 47, 745-758.

RODHAIN J. \& VUYLSTEKE C. Une filaire nouvelle d'Iguana tuberculata (Breinlia brevicaudata n. sp.). Annales de Parasitologie Humaine \& Comparée, 1937, 15, 225-228.

SILVA R.J. \& KohlSDORF T. Tropidurus bispidus Spix 1825 (Sauria, Tropiduridae): a new host for Oswaldofilaria petersi Bain \& Sulahian 1974 (Nematoda, Onchocercidae). Arquivo Brasileiro de Medicina Veterinária e Zootecnia, 2003, 55, 377-379.

SMith A.J. A new filarial species (F. mitchelli $\mathrm{n}$. sp.) found in Heloderma suspectum and its larvae in a tick parasitic upon the gila monster. University of Pennsylvania Medical Bulletin, 1910, 23, 487-497.

Travassos L. Sobre os Filarideos dos Crocodilos sud-americanos. Memórias do Instituto Oswaldo Cruz, 1933, 27, 159-164.

VENTER J.C. Craig Venter reptile database. www.jcvi.org/reptiles/families/tropiduridae.php. 2009

Vicente J.J. Helmintos de Tropidurus (Lacertilia: Iguanidae) da Coleção Helmintológica do Instituto Oswaldo Cruz, II. Nematoda. Atas da Sociedade de Biologia do Rio de Janeiro, 1981, 22, 7-18.

Vicente J.J., Rodrigues H.O., Gomes D. C. \& Pinto R.M. Nematóides do Brasil. Parte III: Nematóides de Répteis. Revista Brasileira de Zoologia, 1993, 10, 19-168.

Reçu le 12 avril 2010 Accepté le 18 juin 2010 